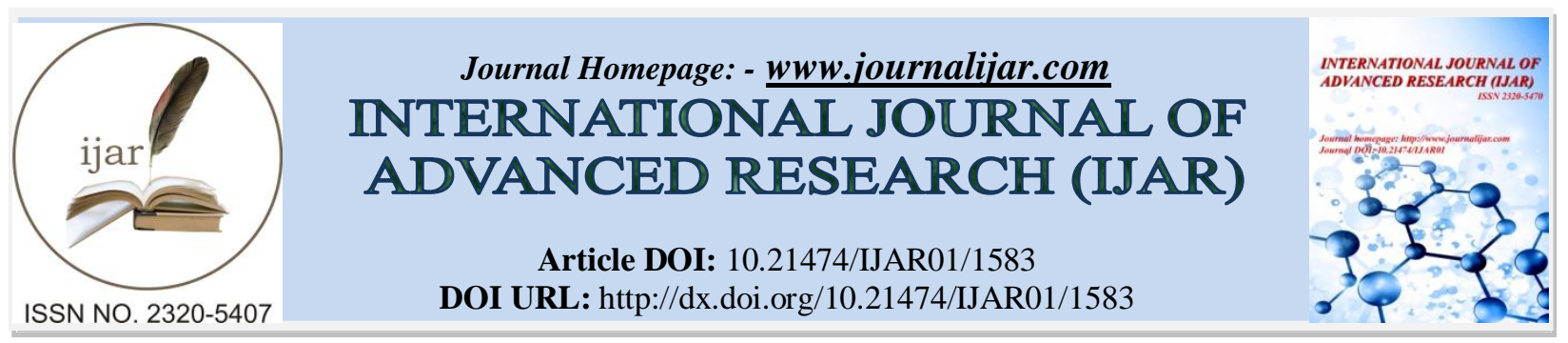

RESEARCH ARTICLE

\title{
COLLECTIVE PURCHASING-CHALLANGES - FARMER PRODUCER COMPANIES IN INDIA.
}

T. Ramesh Reddy, (MBA, MA, Mphil).

\section{Manuscript Info}

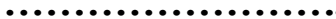

Manuscript History

Received: 15 July 2016

Final Accepted: 16 August 2016

Published: September 2016

\section{Abstract}

Key words:-

Copy Right, IJAR, 2016,. All rights reserved.

\section{OBJECTIVES:-}

Mobilizing farmers in to groups at the village level and build their associations (FPOs) at an Appropriate federating point to plan and implement product specific cluster/ commercial crop cycles

Strengthen farmer capacity through agricultural best practices for enhanced productivity Ensuring access to and usage of quality inputs and services for intensive agriculture enhancing cluster competitiveness

Facilitate access to fair \& remunerative markets including linking producer groups to market opportunities by market aggregators.

Values And Core Principles For Sustaining Of Fpo:-

FPOs are based on the values of self-help, self responsibility, democracy, equality, equity and solidarity. FPO members must believe in the ethical values of honesty, openness, social responsibility and caring for others.

\section{Core Principles $(\mathrm{Cp})$ :-}

FPO principles are the guidelines by which FPOs will put their values into practice.

1st CP: Voluntary and Open Membership FPOs are voluntary organizations, open to all persons able to use their services and willing to accept the responsibilities of membership, without gender, social, racial, political or religious discrimination.

2nd CP: Democratic Farmer Member Control FPOs are democratic organizations controlled by their farmermembers who actively participate in setting their policies and making decisions. Men and women serving as elected representatives are accountable to the collective body of members. In primary FPOs farmer-members have equal voting rights (one member, one vote) and FPOs at other levels are also organized in a democratic manner.

3rd CP: Farmer-Member Economic Participation Farmer-members contribute equitably to, and democratically control, the capital of their FPO. At least part of that capital is usually the common property of the FPO. Farmermembers usually receive limited compensation, if any, on capital subscribed as a condition of membership. Farmermembers allocate surpluses for any or all of the following purposes: developing their FPO, possibly by setting up reserves, part of which at least would be indivisible; benefiting members in proportion to their transactions with the FPO; and supporting other activities approved by the members. 
4th CP: Autonomy and Independence FPOs are autonomous, self-help organisations controlled by their farmermembers. If they enter into agreements with other organisations, including governments, or raise capital from external sources, they do so on terms that ensure democratic control by their farmer- members and maintain their FPO's autonomy.

5th CP: Education, Training and Information FPOs operatives provide education and training for their farmermembers, elected representatives, managers, and employees so that they can contribute effectively to the development of their FPOs. They inform the general public - particularly young people and opinion leaders - about the nature and benefits of FPOs.

6th CP: Co-operation among FPOs FPOs serve their members most effectively and strengthen the FPO movement by working together through local, national, regional and international structures.

7th CP: Concern for the Community FPOs work for the sustainable development of their communities through policies approved by their members.

\section{FPO interventions:-}

The FPO will offer a variety of services to its members as illustrated in the table. It can be noted that it is providing almost end-to-end services to its members, covering almost all aspects of cultivation (from inputs, technical services to processing and marketing). The FPO will facilitate linkages between farmers, processors, traders, and retailers to coordinate supply and demand and to access key business development services such as market information, input supplies, and transport services. Based on the emerging needs, the FPO will keep on adding new services from time to time. The set of services include Financial, Business and Welfare services. An indicative list of services includes:

Collective Purchasing: The FPO will provide low cost and quality inputs to member farmers. It will supply fertilizers, pesticides, seeds, sprayers, pumpsets, accessories, pipelines. Procurement and Packaging Services: The FPO will procure agriculture produce from its member farmers; will do the storage, value addition and packaging

Marketing interventions: The FPO will do the direct marketing after procurement of agricultural produce. This will enable members to save in terms of time, transaction costs, weighment losses, distress sales, price fluctuations, transportation, quality maintenance etc.

Insurance interventions: The FPO will provide various insurance like Crop Insurance, Electric Motors Insurance and Life Insurance.

Financial interventions: The FPO will provide loans for crops, purchase of tractors, pump sets, construction of wells, lying of pipelines.

Technical interventions: FPO will promote best practices of farming, maintain marketing information system, diversifying and raising levels of knowledge and skills in agricultural production and post-harvest processing that adds value to products.

Networking interventions: Making channels of information (e.g. about product specifications, market prices) and other business services accessible to rural producers; facilitating linkages with financial institutions, building linkages of producers, processors, traders and consumers, facilitating linkages with government programmes. 
Role of Producer Company at various Interventions to farmers.

\begin{tabular}{|c|c|c|c|}
\hline S.no & Interventions & $\begin{array}{lll}\text { Small } & \& & \text { Marginal } \\
\text { Farmer } & & \\
\end{array}$ & Producer Company \\
\hline 1 & Marketing & $\begin{array}{l}\text { small volumes, limited } \\
\text { bargaining power }\end{array}$ & aggregation and marketing \\
\hline 2 & Market information & $\begin{array}{l}\text { limited access, but } \\
\text { increasing with the spread } \\
\text { of mobile phones }\end{array}$ & direct links between PC and potential buyers \\
\hline 3 & Transportation & $\begin{array}{l}\text { often time-consuming } \\
\text { and/or costly }\end{array}$ & $\begin{array}{l}\text { transportation is organized within/ facilitated by } \\
\text { the PC }\end{array}$ \\
\hline 4 & Cold storage & no facility & $\begin{array}{l}\text { set up of cold/ripening chambers as shared } \\
\text { infrastructure. }\end{array}$ \\
\hline 5 & Irrigation & $\begin{array}{l}\text { no irrigation facility } \\
\text { dependence on the well } \\
\text { owner/ water supplier }\end{array}$ & $\begin{array}{l}\text { establishment of community wells construction of } \\
\text { collecting tanks laying of pipes. }\end{array}$ \\
\hline 6 & $\begin{array}{l}\text { Extension services and } \\
\text { technology }\end{array}$ & $\begin{array}{l}\text { no access/one-sided } \\
\text { information }\end{array}$ & $\begin{array}{l}\text { farmers' education and regular training sessions } \\
\text { from farmer to farmer, preservation of traditional } \\
\text { farming practices }\end{array}$ \\
\hline 7 & Input supply & $\begin{array}{l}\text { need to buy in the market } \\
\text { credit Problem }\end{array}$ & $\begin{array}{l}\text { provided by the PC at lower than market price } \\
\text { through bulk buying, in-house production of } \\
\text { organic manures and pest killers, links to banks }\end{array}$ \\
\hline 8 & Production planing & short time horizon & $\begin{array}{l}\text { constant information flows of market processes to } \\
\text { the farmer allow a more systematic planning } \\
\text { Approach }\end{array}$ \\
\hline 9 & Excess production & $\begin{array}{l}\text { risk of distress sales or } \\
\text { waste }\end{array}$ & further processing, value addition \\
\hline 10 & Branding & none & brands might be introduced by the PC or the buyer \\
\hline
\end{tabular}

We are going to know the process of Collective Purchasing in the Farmer Producer Companies and Challenges.

Target Farmers: Small and Marginal farmers in selected villages of FPO

\section{Purpose of Collective Purchasing:}

* To make it as entry point activity to bring the trust on collectivization of farmers.

* Minimizing expenses in procuring the input-fertilizer.

\section{Need for Collective Purchasing}

* Doorstep delivery of fertilizers.

* Zero down the additional cost by individual farmers transport,travel and mandays

* Buying fertilizer on less price comparative market price.

* Ensuring the availability of fertilizers prior to monsoon.

* Its an entry point activity to bring the trust among the farmers to move next level in formation of FIG/FPO

* Understanding the importance of collectivization.

* Process ensures supply of quality material.

* Process increases negotiation skills among the farmers with stakeholders.

Operational steps for Collective Purchasing:-

Awareness about Collective Purchasing to the farmers: Organising focused group discussions and awareness meetings .Identifying key farmers and making them to understand.

Aggregate the demand of fertilizer: Micro plan-collection of farmer's names and demand of fertilizer on the basis of product and company.

Formation of Collective Purchasing committees: Organising meetings with interested farmers and identified 3-5 Purchasing committee members from active farmers-who have the knowledge on market scenario, negotiation skills. 
Based on volume of business .Finalized the systems of procurement and payment of amount and distribution of fertilizers.

Identifying fertilizer/Dealer: once price is finalized 100\%amount should be mobilized from the individual farmers enrolled and amount should be paid to distributor on basis of modality (DD/Cash) agreed.

Distribution of fertilizers to farmers at village: As per the mutual agreement ensure the timely delivery of material .Distribution of fertilizers as per the payment made by the farmers with proper acquaintance.

Organizing feedback meeting at village: A meeting should be organized after distribution farmers to know the experience out of this intervention.

Challenges in collective Purchasing:-

Credit system: most of the farmers were depends on local money lender cum Dealer they will provide fertilizers/pesticides/seeds on credit basis, farmer will repay on after harvesting of crop-season.

Price fluctuation: Fertilizer prices always fluctuating day by day but at farmers level once fixed and collection of amount will take time during this time fertilizer price will increase but farmers are fixed for old prices.

Lack of unity: village level so many dynamics will play role -politics, caste poorest of poor and others this all dynamics will create lack of unity among farmers.

Dynamics of market players: once the farmer enters in to the collective purchasing market players will create so many options for farmers to disturb the collectivization.

Failure of monsoons: monsoons also will play a pivotal role during this activity. we will plan and implementation level once monsoons fail farmers will drop from this activity.

\section{Recommendations:- \\ * Regular updation of market prices of fertilizers at farmer level- \\ * Efficient staff at Farmer Producer company level. \\ * Timely delivery of fertilizers to Farmers \\ - Credit system at FPO level. \\ * Ensuring of quality fertilizers to farmers.}

Conclusion:-

Most of the Farmer Producer Companies in Andrapradesh not giving competition to other companies in the aspect of Collective Purchasing because FPO's were mostly depend Resource Intuitions. They need dynamic staff and regular support in day today activities of collective Purchasing.

\section{Case study:-}

As part of startup activities collective purchasing of fertilizers has been facilitated in 3 villages with FIG farmers. Prior to the purchasing the FIGs done micro plan for demand of fertilizers variety and quantity. A purchasing committee is formulated in each village, the committee was approached wholesale dealers and made negotiation with the dealers and lowest quoted dealer has been finalized and purchased.

The FIG members experienced the direct and indirect benefit of collective purchasing. The direct benefit availed by farmers is illustrated in following table. 
Details of Collective purchasing

\begin{tabular}{|l|l|l|l|l|l|l|l|}
\hline S.n & Name & FIG Name & Type & Market & Farmer & Quantity & Benefited \\
\hline o & & & & Price & Price & & \\
\hline 1 & K.Mallikarjuna & Srishailam & $17-17-17$ & $850 /-$ & $780 /-$ & 6 bags & $420 /-$ \\
\hline 2 & K.Govind & Srishailam & $17-17-17$ & $850 /-$ & $780 /$ & $3 \mathrm{bags}$ & $210 /-$ \\
\hline 3 & O.JayaRamudu & Srishailam & $17-17-17$ & $850 /-$ & $780 /$ & $5 \mathrm{bags}$ & $350 /-$ \\
\hline 4 & B.Suranna & Srishailam & $17-17-17$ & $850 /-$ & $780 /$ & $10 \mathrm{bags}$ & $700 /-$ \\
\hline 5 & T.Giddaiah & Srishailam & $17-17-17$ & $850 /-$ & $780 /-$ & $4 \mathrm{bags}$ & $280 /-$ \\
\hline 6 & Ksunkaiah & Srishailam & $17-17-17$ & $850 /-$ & $780 /-$ & $3 \mathrm{bags}$ & $210 /-$ \\
\hline 7 & B.Sudhakar & Srishailam & $17-17-17$ & $850 /-$ & $780 /-$ & $8 \mathrm{bags}$ & $560 /-$ \\
\hline 8 & B.Suresh & Srishailam & $17-17-17$ & $850 /-$ & $780 /-$ & $4 \mathrm{bags}$ & $280 /-$ \\
\hline 9 & B.Prasad & Srishailam & $17-17-17$ & $850 /-$ & $780 /-$ & $8 \mathrm{bags}$ & $560 /-$ \\
\hline 10 & B.Ramanjineyulu & Srishailam & $20-20-0-13$ & $960 /-$ & $930 /-$ & $10 \mathrm{bags}$ & $300 /-$ \\
\hline 11 & B.Govind & Srishailam & $20-20-0-13$ & $960 /-$ & $930 /-$ & $6 \mathrm{bags}$ & $180 /-$ \\
\hline 12 & B.Peddaiah & Vijaya Mallelswari & $17-17-17$ & $850 /-$ & $780 /-$ & $5 \mathrm{bags}$ & $350 /-$ \\
\hline 13 & B.Raju & Vijaya Mallelswari & $17-17-17$ & $850 /-$ & $780 /-$ & $2 \mathrm{bags}$ & $140 /-$ \\
\hline 14 & B.Mallaiah & Vijaya Mallelswari & $17-17-17$ & $850 /-$ & $780 /-$ & $6 \mathrm{bags}$ & $420 /-$ \\
\hline 15 & B.Purusotham & Vijaya Mallelswari & $17-17-17$ & $850 /-$ & $780 /-$ & $4 \mathrm{bags}$ & $280 /-$ \\
\hline 16 & B.Ravi & Vijaya Mallelswari & Spic DAP & $1260 /-$ & $1230 /-$ & $1 \mathrm{bag}$ & $30 /-$ \\
\hline & & Total & & & & $89 \mathrm{bags}$ & $5270 /-$ \\
\hline
\end{tabular}

